\title{
Development of Adobe Flash CS6 Learning Media in Short Story- Based on Learning Text of Advanced Local Community of Batak Toba Students in Tanjungmorawa
}

\author{
Silvia Siburian, Surya Masniari Hutagalung, Syahnan Daulay \\ Universitas Negeri Medan, Indonesia \\ siburiansilvia@gmail.com
}

\section{Abstract}

This study aims to determine the results of the development of Adobe Flash CS6 Learning Media on Short Story Text Learning based on local wisdom. This type of research is research and development based on the ADDIE development model. After going through the development process, a learning media produced Short Story Text based on Local community of the Batak Toba Class XI students of SMA Negeri 1 Tanjung Morawa consists of 4 (four) main menus namely Learning Competencies, Short Story Materials, Learning Quiz and Profile. The results showed that (1) the validation of the material experts included aspects of content Feasibility assessment with a percentage of eligibility of $92.73 \%$ with a predicate of Very Good (SB), a Presentation aspect with a percentage of eligibility of $86 \%$ with a predicate of Very Good $(S B)$, a Language aspect with a percentage of $100 \%$ and the title of Very Good (SB), the aspect of Graphic with a percentage of $90 \%$ with the title of Very Good (SB); (2) validation of media design experts includes aspects of the assessment of Guidelines and Information with a percentage of eligibility of $100 \%$ and the predicate of Very Good (SB), Operational aspects of Software with a percentage of eligibility of $100 \%$ and the predicate of Very Good, Systematic aspects, Aesthetics and Media Principles with a percentage of $98.40 \%$ and a predicate of Very Good (SB); (3) The results of the Field Trial of Teachers and Students obtained a response of $96.15 \%$ with the criteria "Very Good"; (4) Short Text Learning outcomes before using adobe flash CS6 learning media is 51 while Short Text learning outcomes after using adobe flash CS6 learning media is 81 . The difference obtained is $58.23 \%$ from before and after using adobe flash CS6 learning media. So, it can be concluded that the quality of learning media made is "very good".

\section{Introduction}

The quality of human resources is inseparable from education. Education plays an important role in the process of improving the quality of human resources. Education is actually more focused on the teaching and learning process, so that the implementation of the education process is expected to produce quality human resources and be able to compete to face competition in this globalization era (Danim, 2008: 3). Developments in the current era of globalization require development also in the world of education as an effort to improve the quality of human resources. Improving the quality of these resources is necessary in the world of education. 
At present it is known that e-learning based education has become a distinct trend even as a selling point for educational institutions especially distance education. However, in the implementation of learning methods based on e-learning currently still plays a role as a complement to learning that is carried out face to face (conventional). One contributing factor is infrastructure problems, especially the availability of internet networks in low bandwidth quality and relatively expensive prices. In addition, the weak quality of control over elearning education methods such as the inability of students to manage time and process information independently becomes a problem for the organizers of e-learning education.

Achievement of competencies expected in schools must be adjusted to the applicable curriculum with the demands of the times. Currently the curriculum used is the 2013 curriculum. In the 2013 curriculum, Indonesian language learning uses text-based learning. In addition, in the 2013 curriculum implementation, the Indonesian language was also designated as a carrier of knowledge. This function makes language a tool to accelerate the development of the mastery of knowledge that is in line and in tune with the development of language skills. Proficiency in mastering the meaning and structure of Indonesian as well as a wealth of knowledge.

Based on the results of interviews with students in SMA Negeri 1 Tanjung Morawa about teaching literature, especially learning in the short story text in class XI it turns out the interview results show that learning is not interesting because the focus of learning is only on textbooks and teachers.

Based on the problems that arise, the solution found is to develop instructional media using instructional media loaded with local wisdom learning as a support for teaching and learning activities. This is intended so that students can understand the text without having to make up their minds. The purpose of this study are (1) Describe the process of developing Adobe Flash CS6 learning media products on learning short story texts loaded with local wisdom of class XI students. (2) Describe the feasibility of developing Adobe Flash CS6 learning media on learning short story texts loaded with local wisdom of class XI students. (3) Knowing the effectiveness of the use of Adobe Flash CS6 learning media on learning short story texts containing local wisdom of class XI students.

\section{Review of Literature}

The word media comes from the Latin language and is a plural form of the word medium which literally means an intermediary or introduction. Learning media are intermediaries or introductory messages from the sender to the recipient of the message. Many restrictions are given by people about the media. The association of education and communication technology (AECT) in America, for example, limits learning media as all forms and channels that people use to channel messages or information. According to AriefS. Sadiman (2003: 6), the notion of media is an intermediary or messenger of messages from the sender to the recipient of the message.

According to Azhar Arsyad (2003: 3) quoting from the opinions of Gertach and Ely, that the media when understood in broad outline is human or material or events that build conditions that make students able to obtain knowledge, skills, or attitudes.

According to Gagne in Arief S. Sadiman (2003: 6) states that learning media are various types of components in the environment of students that can stimulate them to learn. Meanwhile the opinion of Briggs in Arief S. Sadiman (2003: 6) states that learning media are all physical tools that can present messages and stimulate students to learn, for example: books, films, tapes, film frames. 
According to Santoso S. Hamiddjojo quoted from the book Dientje Borman Rumampuk (1988: 6) educational media are media whose use is integrated with the aims and content of teaching which are usually outlined in the Teaching Program Outlines (GBPP) and intended to enhance the quality of learning activities teach.

From some of the opinions above there are similarities including learning media is things that can channel messages, can stimulate the thoughts, feelings, and wishes of students so as to encourage the creation of learning processes in students themselves. According to the meaning of the media outlined above, then the existence of the media in the learning process is a need that must be met. By using media, students have a uniform perception of the material delivered by the teacher, so there is no difference in information between students in receiving the material given.

From the description above it can be concluded that learning media are all things that can be used to channel messages from the sender to the recipient so that they can stimulate the thoughts, feelings, interests and attentions of the participants so that the learning process occurs.

Sukirman (2012: 45) suggests the use of learning media in the learning process of students, namely: (1) learning will attract more attention of students so that it can lead to learning motivation, (2) learning materials will be clearer so the meaning is easily understood by students and enable it to master and achieve learning goals, (3) learning methods will be more varied, not solely verbal communication through speech by the teacher so students are not bored and teachers do not run out of energy, (4) Students can do more learning activities because they are not only listen to the teacher's direction, but also other activities such as observing, doing, demonstrating, acting and others.

Based on the opinion above it can be concluded that the function of learning media can help facilitate learning for students and educators, provide more tangible experiences (abstract to be concrete), attract the attention and interest in learning of students, and can evoke an equalization between theory and reality.

Based on the perception of the senses. Media is classified into three classes, namely audio media, visual media, and audio visual media (Sanaky, 2011: 42). Audio media is media that produces sound or sound. Media can channel messages through sound or sound. Examples of this type of media are radio and audio cassette tapr recorders. Visual media are media that produce shapes or shapes, known as visual media. Examples of visual media are pictures of transformers, insectarium, imitations of human skeletons, and others. Visual media are divided into two types, namely (1) two-dimensional visual media and (2) threedimensional visual media. Audio visual media, which is media that can produce images and sounds in one media unit. Examples of this type of media are video, sound film, and television.

Based on the way the use of instructional media can be divided into two, namely learning media that are used in (1) traditional or conventional (simple) and (2) modern or complex. In terms of complexity and cost, Schramm as quoted by Sanaky (2001) distinguishes between complicated and expensive media (big media) and simple media (little media). Big media examples are learning videos and educational television broadcasts. Little media examples are images of stars and Landscape pictures, such as food chain sketches in biology learning. Schram also groups media according to their reporting capabilities, namely: 1) wide and concurrent coverage such as TV, Radio, Fax, 2) coverage is limited to places / rooms such as films, videos, slides, posters, audio tapes, and so on. 3) media for individual learning (independent) such as books, modules, computer and telephone learning programs. 
Classification of learning media, especially audio-visual media, is carried out by C.J.Ducan, by compiling a hierarchy. From the hierarchy described by Ducan, it can be concluded that the higher the level of a media hierarchy, the lower the unit cost, and the more specific the nature of its use. However, the ease and flexibility of the nature of its use increases. low.

Arsyad (2002: 216) said In line with technological developments, the learning media also developed through the use of the technology itself. Based on the development of these technologies, the media are classified into four groups namely 1). Media technology results of students. 2). audio visual result media. 3). computer-based technology media. 4). the combined media of print and computer technology.

In this research, an audiovisual learning media will be developed which is developed using a graphic design as a tool to assemble it. Utilization of graphic design programs in this study is assumed to be more productive and the resulting product will attract the user's attention because of its ease of use. The audiovisual learning media is processed using Adobe Flash graphic design programs.

Adobe Flash software, hereinafter referred to as Flash, was formerly called "Macromedia Flash", superior multifunction software previously developed by Macromedia, but now developed and distributed by Adobe System. Since 1996, Flash has become a popular method for adding animation and interactive websites. Flash is not superior multifunction software previously developed by Macromedia, but now developed and distributed by Adobe System. Since 1996, Flash has become a popular method for adding animation and this is only used for web applications, but can also be developed to build desktop applications because Flash applications are not only compiled into .swf format, Flash can also be compiled (combined) into .exe format (Sunyoto 2010: 1).

Adobe Flash is the chosen device for developing Learning Media. Adobe Flash is an animation program that supports programming with programming languages or action scripts. Therefore, Flash is appropriate for developing Learning Media because it supports animation, images, text, and other programming. Flash also designed with the ability to create twodimensional animation so that this program is widely used to provide website animation effects, interactive CDs, and others.

In this study, using Adobe Flash Professional CS6 as the latest application to create Learning Media. Although the Adobe Flash application below it can still be used. Adobe Flash Creative Suite 6 (CS6) is a software specifically designed by Adobe and a standard application program for professional authoring tools used to create Learning Media and animations that are very attractive for the purposes of developing interactive and dynamic learning media (Wibawanto 2017: 30) . Adobe Flash Professional CS6 provides a variety of features that will help and make it easier for animators to make animation even more interesting.

\section{Research Method}

This type of research is research and development, namely the development of instructional media using Adobe Flash CS 6 on short-term text material based on local wisdom in class XI students of SMA Negeri 1 TanjungMorawa. According to Sugiyono (2016: 297), research and development methods are research methods used to produce certain products and test the effectiveness of these products. Tegeh et al (2014: 13), development research is a research method that is effective enough to improve learning practices, with the aim of developing new products or improving existing products so that they can be accounted 
for. This research and development refers to the theory of teaching material development proposed by Borg and Gall.

In designing this learning media, the ADDIE learning model consists of five main phases, namely: Analysis, Design, Development, Implementation, and Evaluation. The five phases or stages in the ADDIE model need to be done systematically.

Analysis is the initial stage used in learning design. This stage is a stage that explains the things that must be learned by students. This analysis is also used to clarify whether there are problems that will be faced so that later can find the right solution to deal with problems in the implementation of learning programs.

Design is the stage after the analysis process where this stage is not a follow-up or core activity of the analysis step. Learning design is also said to be a design in the learning process. The design is compiled by studying the problem, then finding a solution through identification of the requirements analysis stage in the previous process. One of the goals of this stage is to determine the right learning strategy so that students can achieve goals in the education process, especially in achieving the competency standards that have been determined in the learning process.

After the formation of the learning design in the second stage, the next stage is the development or development stage, where the designs that are already composed or already made are then followed up by a process of testing. Whether the design has been made is suitable for use or not. If the design that was tested was successful or can be used, then the design must be developed to be better and certainly support the learning process to achieve its goals.

This development phase must also be combined or integrated with the media presumably to support learning. In addition, the things around him must naturally be related and support one another. Therefore, learning will run well if one thing with another is connected properly.

A learning plan that has been made we will not know the results if there is no action taken. The existence of these actions is very means the implementation or implementation of a plan where this is one of the ADDIE models which is integrated with the previous stages as a refinement and is quite influential in the implementation of learning.

A well-prepared learning plan will pass the stages of developing the ADDIE model smoothly and end at a stage called evaluation. Evaluation is the stage where the action taken is aimed at knowing the success of a learning plan, things that are done for the success of this stage are not solely intact at this stage, but evaluation can also occur in the previous stages.

The analysis phase is a process of defining what the learning participants will learn, namely analyzing needs, identifying problems, and doing task analysis. (Muhammad Afandi and Badarudin, 2011: 24). So that the expected results can be in accordance with the things expected beforehand.

The data obtained is data about the state of Indonesian teaching materials in the short text material. This data was collected through expert validation, questionnaires / questionnaires distributed to students. Assessment instruments for validators and individual trials, small groups and limited field groups, Then the data were analyzed in quantitative descriptive terms, namely calculating the percentage of indicators for each category in the teaching material developed .

The location of the study was in SMA Negeri 1 Tanjung Morawa. The reason for this research location is because this school has been supported by adequate infrastructure but there are no language teachers who use Adobe Flash CS 6 based learning media. In addition, 
the teaching materials available are not based on local wisdom. This research was conducted from October to November 2019.

\section{Discussion}

Research that has been done is a type of research development (Research and Development), namely the development of instructional media using Adobe Flash CS 6 on short-term text-based local wisdom material in class XI students of SMA Negeri 1 Tanjung Morawa. The development method uses the ADDIE model, which consists of five main phases, namely: Analysis, Design, Development, Implementation, and Evaluation. The five phases or stages in the ADDIE model are carried out systematically. The product of this research is in the form of developing Adobe Flash CS 6 learning media on Short Story Text Material learning or what is called digital media. Following are the stages of product development in the form of instructional media Short Story Text Material based on Adobe Flash CS 6 application.

Curriculum analysis conducted in class XI of SMA Negeri 1 Tanjungmorawa is the 2013 curriculum. The 2013 curriculum aims to encourage students to be more active in conducting, observing, asking questions, gathering information, negotiating, communicating and creating. So, students are active in learning activities. These curriculum demands are in accordance with the benefits of using the Adobe Flash CS 6 application in the learning process.

In carrying out the learning of Short Story Text Material it is not enough just by the lecture method, variation of learning is needed in order to cause students to feel a sense of interest in the subject matter delivered, in this case the use of media based on Adobe Flash CS 6 can be used as a solution to support learning. Therefore, it is necessary to develop a learning media based on Adobe Flash CS 6 that is good for Short Story Text Material so that all material information can be conveyed with innovative media.

Before further media development is carried out, it is better to first carry out an analysis of field needs regarding the needs of Adobe Flash CS 6 based learning media. This analysis is intended to adjust the design of the media to be equipped with features desired by the user later. A needs analysis in the form of a survey was conducted on 2 Indonesian teachers and 32 students. Initially, most students were not familiar with Adobe Flash CS 6 learning media.

Based on the results of the needs analysis of 32 students, 32 students have never used the Adobe Flash CS 6 learning media application in learning Short Story Text material. Then, the results of the needs analysis also showed that as many as 32 students wanted Short Text Text learning material taught using the Adobe Flash CS 6. application. Based on the results of the analysis above, it can be concluded that the students were interested in and needed learning media based on Adobe Flash CS 6. Furthermore, the needs analysis conducted on Indonesian Language Teachers and the following are presented the results of an analysis of the teacher's needs of the learning media Adobe Flash CS 6.

Based on the results of the analysis of the needs of 2 (two) teachers obtained survey results where 2 (two) teachers said they did not use Adobe Flas learning media CS 6 in learning Short Text material and 2 (two) teachers feel it is important to use Adobe Flash CS 6 learning media applications in learning Short Text material. The results of the analysis of the needs of these teachers prove that these teachers are interested and in dire need of learning media based on Adobe Flash CS 6.

At this stage the literature survey and the material to be taught are Short Story Text Material. Understanding short stories (short stories) have been made and put forward by literary experts, and writers. Definitely not easy to make a definition of a short story. Material 
analysis aims to identify the main parts that students will learn on the subject of Short Text Material.

Based on the description of the results of the study, it can be concluded that relating to the development of interactive multimedia on the learning of Short Story Text Material in SMA Negeri 1 Tanjung Morawa students, the conclusions obtained based on the formulation of the problem, research objectives, results, and discussion, can be described as follows: Teachers and Students need Adobe Flash CS 6 learning media in the learning process where the percentage level of the needs of Teachers and Students for Adobe Flash CS 6 learning media is $100 \%$ meaning that all students and teachers strongly agree with the development of Adobe Flash CS 6 based learning media products. Test results Feasibility by media and material design experts got an average percentage of eligibility of $98.95 \%$ with the criteria of "Very Good" in developing Adobe Flash CS 6 learning media on Short Story Text Material Learning. Field Trial Results for Teachers and Students obtained a percentage of eligibility of $96.15 \%$ deng and the criteria of "Very Good" in the development of learning media Adobe Flash CS 6 on Short Story Text Material Learning. The effectiveness of learning media based on Adobe Flash CS 6 on Short Story Text Learning Material scored 58.23\% from an average value of 81 greater from the average value of students before using Adobe Flash CS 6 learning media in Short Story Text Material Learning that is 51. The acquisition of the average value of these students has met the KKM standard with the predicate level of completeness "Good"

\section{Conclusion}

After the media development was applied to the XI students of SMA Negeri 1 Tanjung Morawa, it can be seen that the students' interest increased, the results were in line with the opinion of Sukirman (2012: 45) suggesting the use of instructional media in the learning process of students, namely: (1) learning will attract more attention of participants students so that it can lead to learning motivation, (2) learning materials will be clearer meaning so that it is easy for students to understand and enable them to master and achieve learning objectives, (3) learning methods will be more varied, not merely verbal communication through speech by the teacher so students are not bored and teachers do not run out of energy, (4) students can do more learning activities because not only listen to the teacher's direction, but also other activities such as observing, doing, demonstrating, acting out.

\section{Reference}

Afandi Muhammad dan Badarudin. (2011). Perencanaan Pembelajaran. Bandung Alfabeta Ah-Sanaky, H. (2011). Media Pembelajaran Buku Pegangan Wajib Guru Dan Dosen. Yogyakarta : Kaukaba Dipantara.

Aksan, Hermawan. 2011. Proses Kreatif Menulis cerpen. Bandung: Nuansa

Arief S. Sadiman. 2003. Media Pendidikan. Jakarta: Raja Grafindo Persada. Arsyad, Azhar. 2002. Media Pembelajaran, edisi 1. Jakarta: PT. Raja Grafindo Persada.

Astawa, I Gede Santi. 2012. "Sistem Tutorial Matematika Diskret dalam Menunjang Proses Belajar Berbasis Komputer”. Jurnal Ilmu Komputer. Volume 5 No. 2 September 2012:17-22.

Azwar Syarifudin, 2016. Pengembangan Media Adobe Flash Sebagai Media Pembelajaran Pada Materi Menulis di SMA Negeri 15 Yogyakarta. 
Danim, Sudarwan. 2008. Kinerja Staf dan Organisasi Perspektif Pendidikan, Pelatihan, Pengembangan Kewidyaiswaraan Berbasis Kinerja. Bandung Pustaka Setia

Deima, M. \& Keller, J.M. (2006). Volitional Aspect of Multimedia Learning. Journal of Educational Multimedia and Hypermedia, 15 (2), 137-158 Educational Communication and Technology" Journal. 30, 195-232.

Djamarah, Syaiful Bahri dan Aswan Zain. 2010. Strategi Belajar Mengajar. Jakarta: Rineka Cipta.

Geertz, Clifforrd. 2004. Local Knowledge and it's Limit. Yale: Johns Hopkins University Press

Hannafin, Michael J \& Peck, Kyle L. (1988). The Design, Developmentand Evaluation of Instructiononal Software. New York: Macmilan Publishing Company.

Hidayati, Panca P. (2009). Teori Apresiasi Prosa Fiksi. Bandung: Prisma Press Prodaktama

Kartadinata, Sunaryo. 1997. Pendidikan untuk Pengembangan SDM Bermutu

Memasuki Abad XXI: Implikasi Bimbingannya. Makalah Konvensi Nasional Divisi-Divisi IPBI. Purwokerto, 11-14 Desember 1997.

Keller, Kevin Lane. 2003. Strategic Brand Management: Building, Measuring, and Managing Brand Equity. New Jersey: Prentice Hall.

Keraf, G. (1994). Komposisi. Jakarta: Nusa Indah.

Kemendikbud Tahun 2014 Pengertian Gaya Bahasa dan Struktur Cerpen. Jakarta: Depdiknas

Koesoema, 2007. Pendidikan Karakter: Strategi Mendidik Anak di. Zaman Global. Jakarta. PT Grasindo.

Kosasih, E. (2014). Jenis-Jenis Teks. Bandung: Yrama Widya

Leacock, T. L., \& Nesbit, J. C. 2007. A Framework for Evaluating the Quality of

Multimedia Learning Resources. Educational Technology \& Society, 10 (2), 44- 59.

Muller, D.A., Lee, K.J. \& Sharma, S.D. (2008). Coherence or interest: which is most important in online multimedia learning? Australian Journal of Educational Technology, 24 (2), 211-221.

Nurgiyantoro, B. 2010. Penilaian Pembelajaran Bahasa. Yogyakarta: BPFE

Nurgiyantoro, burhan. 2010. Teori Pengkajian Fiksi (cet. Kedelapan ). Yogyakarta

Nur Hady. 2018. Pengembangan Media Pembelajaran Adobe Flash CS 6 Berbasis Kearifan Lokal untuk peserta didik SMP

Priyatni, Endah Tri. 2010. Membaca sastra dengan ancangan literasi kritis. Jakarta: Bumi Aksara.

Purba, Antilan. 2010. Sastra Indonesia Kontemporer. Yogyakarta: graha Ilmu

Rahman. 2009. Kemampuan Menulis. http://faisal14.wordpress.com/2009/03/02/cara-menulis daftar-pustaka/, 12 Mei 2011

Ridwan, Nurman Ali. 2007. Penelitian 'Landasan Keilmuan Kearifan Lokal'. Purwekerto: STAIAN Purwekerto

Rumampuk, Dientje Borman. 1988. Media Instruksional IPS. Departemen Pendidikan dan Kebudayaan Direktorat Jenderal Pendidikan Tinggi Jakarta

Sadiman, Arief S. dkk. 2011. Media Pendidikan: Pengertian Pengembangan, dan Pemanfaatannya. Jakarta: Grafindo Persada.

Sanjaya, Wina. 2014. Penelitian Pendidikan, Jenis, Metode dan Prosedur. Jakarta: Kencana Prenada Media Group.

Sartini. 2006. Menggali Kearifan Lokal Nusantara Sebuah kajian Filsafat.(online) (http://filsafat.ugm.ac.id), diakses tanggal 22 Februari 2016 
Sayuti, Suminto A. 2010. Kearifan Lokal dalam Konteks Pendidikan Karakter. Makalah Seminar Nasional "Pendidikan Karakter Berbasis Kearifan Lokal untuk Menghadapi Tantangan Global”. Yogyakarta: Lemlit UNY

Steven. J. M. 2010. Instructional Systems Design (ISD): Using The ADDIE Model. College of Education: Penn State University.

Sugiyono. 2011. Metode Penelitian Kuantitatif, Kualitatif dan $R \& D$. Bandung: Afabeta Sugiyono. 2016. MetodePenelitian Kuantitatif, Kualitatif dan R\&D. Bandung: PT Alfabet.

Sukatman. 2017. Pengembangan Media Pembelajaran Berbasis Adobe Flash Pada Materi Memproduksi Pementasan Drama di kelas XI SMA Negeri 1 Kalisat.

Sukirman. 2012. Pengembangan Media Pembelajaran. Yogyakarta: PT Pustaka Insan Madani

Sumardjo, Jakob and Saini K.M. 1995. Apresiasi Kesusastraan. Jakarta: Gramedia

Sumardjo et al, 2004. Teori dan Praktek Kemitraan Agribisnis Penebar Swadaya. Jakarta.

Sumardjo, J. 2004. Seluk Beluk Cerpen. Bandung: Pusataka Latifa

Suyanto, Edi. 2012. Pendidikan dan PelatihanProfesi Guru (Pendalaman Materi Bahasa Indonesia). Bandar lampung: Universitas Lampung. $60 \mathrm{hlm}$.

Sunyoto A. 2010. Adobe Flash + XML = Rich Multimedia Application. Yogyakarta: ANDI.

Supriadi ,Dedi. 1996. Mengangkat citra dan martabat guru. Yogyakarta : Aditcita karya Nusa.

Supriatna, D., dan Mulyadi, M. 2009. Konsep dasar desain pembelajaran. Pusat Pengembangan dan Pemberdayaan Pendidik dan Tenaga Kependidikan Taman Kanakkanak dan Pendidikan Luar Biasa.

Tarigan, Henry Guntur. 1994. Menyimak Sebagai Suatu Keterampilan Berbahasa. Bandung: Angkasa.

Tarigan, Henry Guntur dan Djago Tarigan. 2011. Pengajaran Analisis Kesalahan Berbahasa. Bandung: Angkasa Bandung.

Tegeh, I Made, dkk.2014. Model Penelitian Pengembangan. Yogyakarta: Graha Ilmu.

Tiezzi, E, Marchettini, T. \& Rossini, M.TT. Extending the Environmental Wisdom beyond the Local Scenario: Ecodynamic Analysis and the Learning Community. http:library.witpress.com/pages/paperinfo.asp

Wibawanto, Wandah. 2017. Desain dan Pemrograman Multimedia Pembelajaran Interaktif. Jember: Cerdas Ulet Kreatif 